Like the mast cells of the precancerous mouse skin, the mast cells of the precancerous skin of the lizard probably contain a relatively large quantity of histamine and 5-hydroxytryptamine.

The source of 5-hydroxytryptamine is unknown; it may be either the inside or the outside of the precancerous epidermis. Possibly this substance plays an important part in the development of the squamous-cell carcinoma of the skin.

Histological Laboratory,

A. SToLK

Free University,

Amsterdam.

Aug. 29.

'Woglom, W., Arch. Path., 2, 533, 709 (1926).

2 Riley, J. F., Experientia, 14, 141 (1958).

${ }^{3}$ Holmgren, H., and Wohlfart, G., Cancer Res., 7, 686 (1947).

- West, G. B., and Parrat, J. R., Arch. dermatol, 76, 336 (1957).

s Benditt, E. P., and Wong, R. L., J. Exp. Med., 105, 509 (1957).

6 stolk, A., Thesis, Utrecht (1950).

'stolk, A., Proc. Kon. Ned. Akad. Wet., 56, 157 (1953)

"Casselman, W. G. B., Quart. J. Micro. Sci, 95, 321 (1954).

\section{Undergraduate Academic Record of Fellows of the Royal Society}

THE communication by Gross and Hudson in Nature of September 20, p. 787, shows an interesting difference between academic records of Fellows of the Royal Society who were respectively at Cambridge and at Oxford. Of those at Cambridge only about 77-78.5 per cent achieved a first, and in fact only about 55 per cent achieved a first in both parts of a tripos. The Fellows of the Royal Society who were at Oxford, on the other hand, graduated with first-class honours in about 97 per cent of cases.

The authors suggest that these interesting results are open to at least two interpretations: (1) that the Oxford examination is a more valid index of potential research ability ; and (2) that the standards of the Oxford examinations are relatively lower than those of Cambridge. There is surely a very important third possible interpretation, namely, extra-curricular activities are far more interesting at Cambridge than at Oxford, and that in the widest sense the Cambridge education is therefore better.

The authors, strangely, make no comment on the fact that it seems to be three times as common for a Cambridge graduate to become a Fellow of the Royal Society, neither do they comment on the obvious fallacy of the whole investigation, namely, the opportunities for research offered to a young man at the beginning of his career. If these are, for example, only offered to those with a first-class degree, it is obvious that selection for the fellowship of the Royal Society in later years will be almost restricted to those who had first-class degrees. The method will fail to show whether there is a number of potentially good investigators among those with second-class degrees who have never been given the opportunities for a career in research.

\section{Department of Medicine, \\ The Royal Infirmary,} Manchester 13.

Robert Platt

We certainly agree with Prof. Platt that the difference between the Oxford and Cambridge results is open to the third possible interpretation that he suggests, and we would welcome from him any suggestion as to how we could measure the "more interesting" nature of the "extra-curricular activities" at Cambridge.

We find nothing strange in "the fact that it seems to be three times as common for a Cambridge graduate to become a Fellow of the Royal Society" since there are almost three times as many science graduates from Cambridge as there are from Oxford.

During the period $1920-39$, approximately 4,700 natural scientists, 1,400 mathematicians and 1,800 engineers graduated from Cambridge, while only 2,600 natural scientists (including engineers) and 400 mathematicians graduated from Oxford.

If we understand Prof. Platt's last paragraph correctly, we consider it to be true but irrelevant to our study and to the general problem under consideration. Obviously, as he points out, if only students with first-class degrees are given opportunities for research, the Fellows of the Royal Society will be drawn largely from this group. Our point is that, whatever selection procedures were used in the past, a considerable minority of the scientists elected to the Royal Society did not receive first-class degrees. From this we conclude that it may be unwise to use class of degree as the primary criterion for the award of research grants.

\section{Gross}

L. Hupsox

Psychological Laboratory, Cambridge.

\section{Cancer and Smoking}

IN a letter published in Nature of August 30 , p. 596, Sir Ronald Fisher quoted figures confirming previous observations that smoking habits are more similar in identical than in fraternal pairs of twins even when the identical pairs are reared apart. The result can be interpreted as showing that, like almost every trait, mental or physical, previously tested by the twin method, smoking habits are, to a greater or lesser degree, dependent upon genetical constitution. It is, however, difficult to appreciate the ralevance of this demonstration to the problem as to whether or not cigarette smoking causes lung cancer.

The association between epithelioma and the occupation of sweeping chimneys has been well known in the past. Not improbably it could have been proved that identical twins were more often both chimney sweeps than would have been expected by chance. Such a finding would not have influenced the case for assuming a strong causal connexion between soot irritation and epithelioma.

Nevertheless, there are perhaps hitherto unexplored ways in which twin data might be usefully employed in the study of the effects of tobacco on the lungs. Pairs of identical twins, whose smoking habits were discordant, could be followed up with special reference to possible development of lung disorders in one or both members.

Galton Laboratory,

L. S. Penrose

University College,

Gower Street,

London, W.C.l. 